\title{
PEMANFAATAN LARUTAN GARAM NATRIUM KLORIDA (NaCl) SEBAGAI PENGAWET ALTERNATIF PADA URINE UNTUK PEMERIKSAAN URINE METODE CARIK CELUP
}

\author{
Baiq Nasha Islaeli ${ }^{1}$, Maruni Wiwin Diarti ${ }^{2}$, Yudha Anggit Jiwantoro ${ }^{3}$ \\ Jurusan Analis Kesehatan, Poltekkes Kemenkes Mataram, Indonesia
}

\section{Article Info \\ Article history: \\ Received Jan $11^{\text {st }}, 2019$ \\ Revised Jan $14^{\text {th }}, 2019$ \\ Accepted Feb $18^{\text {th }}, 2019$}

Keyword:

$\mathrm{NaCl}$ Salt

Urine

Dipstick Method

\begin{abstract}
Urine examination is done for the sake of diagnosis, one of which is controlling treatment in DM patients. Diabetes Mellitus has a risk of urinary tract infection (UTI). Based on the SOP In Microbiology, urine samples must be immediately examined less than 2 hours after taking. This delay will increase bacterial growth. If a delay occurs, preservative urine samples can be added. One alternative preservative that can suppress bacterial growth is salt $(\mathrm{NaCl})$. The objective of this research is to find out the benefits of sodium chloride $(\mathrm{NaCl})$ salt solution as an alternative preservative in urine for urine examination of dipstick method. This study is a Pre-Experimental study with a One Group Pretest-Posttest design. The respondent's urine sample added a concentration of $\mathrm{NaCl}$ salt solution of $3.5 \%, 4.0 \%$, and $4.5 \%$ and then left for 12 hours. The results showed that salt solution concentrated at $3.5 \%, 4.0 \%$, and $4.5 \%$ able to maintain leukocyte esterase and nitrite levels in urine which was left to stand for 12 hours. The amount of erythrocytes in urine can be maintained by the addition of saline solution concentrations of $3.5 \%$ and $4.0 \%$. While the addition of $\mathrm{NaCl}$ salt solution does not affect the urine glucose which is left for 12 hours. The conclusion of this research is $\mathrm{NaCl}$ salt solution concentration of $3.5 \%$ and $4.0 \%$ can be used as an alternative preservative in urine for leukocyte esterase, nitrite and erythrocyte parameters
\end{abstract}

Copyright $(\odot$ Jurnal Analis Medika Bio Sains All rights reserved.

\footnotetext{
ABSTRAK

Pemeriksaan urine dilakukan untuk kepentingan diagnosis, salah satunya adalah mengontrol pengobatan pada pasien DM. Diabetes Mellitus memiliki resiko terjadinya infeksi saluran kemih (ISK).Berdasarkan SOP In Microbiology, sampel urine harus segera diperiksa kurang dari 2 jam setelah pengambilan. Penundaan ini akan meningkatkan pertumbuhan bakteri. Jika terjadi penundaan, sampel urine dapat ditambahkan pengawet. Salah satu pengawet alternatif yang dapat menekan pertumbuhan bakteri adalah garam $(\mathrm{NaCl})$. Tujuan dari penelitian ini adalah untuk mengetahui manfaat larutan garam natrium klorida $(\mathrm{NaCl})$ sebagai pengawet alternatif pada urine untuk pemeriksaan urine metode carik celup. Penelitian ini merupakan penelitian Pra Eksperimen dengan rancangan One Group Pretest Posttest. Sampel urine responden ditambahkan larutan garam $\mathrm{NaCl}$ konsentrasi 3,5\%, 4,0\%, dan 4,5\% lalu didiamkan selama 12 jam. Hasil penelitian menunjukkan bahwa larutan garam konsentrasi 3,5\%, 4,0\%, dan 4,5\% mampu mempertahankan kadar leukosit esterase dan nitrit pada urine yang didiamkan selama 12 jam. Jumlah eritrosit dalam urine dapat dipertahankan dengan penambahan larutan garam konsentrasi 3,5\% dan 4,0\%. Sedangkan penambahan larutan garam $\mathrm{NaCl}$ tidak berpengaruh terhadap glukosa urine yang didiamkan selama 12 jam. Kesimpulan yang dapat diambil dari penelitian ini adalah larutan garam $\mathrm{NaCl}$ konsentrasi $3,5 \%$ dan $4,0 \%$ dapat dijadikan sebagai pengawet alternatif pada urine untuk parameter leukosit esterase, nitrit, dan eritrosit.
} 


\section{Pendahuluan}

Urinalisis adalah salah satu pemeriksaan laboratorium yang penting untuk menegakkan berbagai diagnosis ${ }^{1}$. Urinalisis juga merupakan pemeriksaan kimia yang umum dilakukan pada anakanak dan remaja ${ }^{2}$. Indikasi dilakukan pemeriksaan urine yaitu untuk kepentingan diagnosis, salah satunya yaitu mengontrol pengobatan pada pasien Diabetes Mellitus. Diabetes Mellitus memiliki sejumlah efek jangka panjang pada sistem urogenital dan efek ini merupakan resiko terjadinya Infeksi Saluran Kemih. Resiko terjadinya ISK pada pasien DM di dunia diperkirakan sebesar $60 \%$ dan di Indonesia sebesar $47 \%{ }^{3}$. ISK umumnya ditandai dengan adanya bakteri golongan Enterobacteriaceae. Bakteri dalam urine penderita Diabetes Mellitus dapat mengalami peningkatan jika sampel urine tidak langsung diperiksa atau mengalami penundaan pemeriksaan.

Jika urine disimpan kemungkinan terjadi perubahan susunan oleh kuman-kuman. Kumankuman mengurai ureum dengan membentuk amoniak dan CO2. Amoniak menyebabkan pH urine menjadi basa dan terjadilah pengendapan kalsium dan magnesium fosfat. Selain itu juga glukosa akan diurai oleh kuman-kuman sehingga hilang dari urine. Penundaan pemeriksaan terhadap spesimen urine harus dihindari karena dapat mengurangi validitas hasil. Analisis harus dilakukan selambat-lambatnya 4 jam setelah pengambilan specimen ${ }^{4}$. Penundaan pemeriksaan ini juga dapat mempengaruhi hasil pemeriksaan kimia urine.

Metode yang paling umum digunakan untuk uji kimia pada urine adalah metode dipstick (carik celup). Uji ini dapat menunjukkan rentang kandungan kimia yang ada pada urine. Meskipun metode ini terlihat mudah namun merupakan reaksi kimia yang kompleks. Reaksi yang terjadi dipengaruhi oleh beberapa faktor, salah satunya adalah adanya bakteri pada urine. Parameter yang akan dipengaruhi oleh peningkatan bakteri ini yaitu glukosa, leukosit esterase, nitrit, dan blood. Salah satu upaya untuk mengurangi atau menghambat pertumbuhan bakteri adalah menggunakan pengawet ${ }^{5}$.

Salah satu pengawet urine yang paling banyak digunakan adalah Toluena. Namun, karena sifat toluena yng berbahaya dan mahal, diperlukan pengawet yang ramah lingkungan serta murah dan mudah diperoleh, seperti garam Natrium Klorida $(\mathrm{NaCl})$ Penggaraman merupakan teknik pengawetan yang dilakukan secara sederhana dan tradisional. Garam digunakan sebagai pengawet karena garam mampu menghambat mikroorganisme secara selektif.

Garam yang digunakan pada proses penggaraman memiliki sifat bakteriostatik dan bakteriosidal yang memilki kemampuan untuk menunda pertumbuhan atau membunuh bakteri. Selain itu, bakteri ini juga mudah dimatikan atau dihambat pertumbuhannya dengan desinfektan konsentrasi rendah seperti fenol, formaldehid, komponen halogen karena bersifat bakterisid. Contoh senyawa halogen yang digunakan sebagai desinfektan adalah Povidon-iod, Iodoform 7,5-10\%, Ca-hipoklorit, Na-hipoklorit, 
Tosilkloramida, Klorheksidin 2-4\%, Kliokinol, dan Triklosan 0,2-2\% . Berdasarkan hasil penelitian yang telah dilakukan oleh Rahayu $(2013)^{7}$, bahwa bakteri golongan Enterobacteriaceae yaitu Eschericia Coli dapat dihambat oleh ekstrak buah melur dengan konsentrasi 3,12\%. Oleh karena itu, perlu dilakukan penelitian lebih lanjut mengenai konsentrasi optimum yang dapat menghambat pertumbuhan bakteri Enterobacteriaceae agar tidak mempengaruhi hasil pemeriksaan kimia urine.

Tujuan penelitian ini adalah untuk mengetahui hasil pemeriksaan urine metode carik celup dengan penambahan larutan garam Natrium Klorida $(\mathrm{NaCl})$ sebagai pengawet alternatif pada urine.

\section{Metode Penelitian}

Penelitian ini merupakan penelitian Pra Eksperimen dengan desain penelitian yang digunakan adalah One Group Pretest Postest Design. Sampel yang digunakan adalah urine sebanyak 6 sampel. Sampel urine diperiksa dengan carik celup sebanyak 2 kali. Pemeriksaan pertama untuk melihat hasil glukosa, leukosit esterase, nitrit, dan eritrosit pada urine sebelum ditambahkan larutan garam $\mathrm{NaCl}$ konsentrasi 3,5\%, 4,0\%, 4,5\%. Pemeriksaan kedua untuk melihat hasil glukosa, leukosit esterase, nitrit, dan eritrosit pada urine setelah ditambahkan larutan garam $\mathrm{NaCl}$ konsentrasi 3,5\%, 4,0\%, 4,5\% dan disimpan selama 12 jam. Hasil pemeriksaan urine disajikan dalam bentuk tabel kemudian data yang diperoleh di analisis secara deskriptif dengan membandingkan hasil pemeriksaan glukosa, leukosit esterase, nitrit, dan eritrosit pada urine sebelum dan setelah ditambahkan larutan garam $\mathrm{NaCl}$.

\section{Hasil Penelitian dan Pembahasan}

Berdasarkan penelitian yang dilakukan, didapatkan hasil pemeriksaan glukosa, leukosit esterase, nitrit, dan eritrosit pada urine yang dapat dilihat pada tabel di bawah ini:

Tabel 1. Hasil Pemeriksaan Glukosa Urine Metode Carik Celup Sebelum dan Setelah Penambahan Larutan Garam $\mathrm{NaCl}$

\begin{tabular}{c|cccccc}
\hline \multirow{2}{*}{$\% \mathrm{NaCl}$} & \multicolumn{7}{|c}{ Replikasi } \\
\cline { 2 - 7 } & 1 & 2 & 3 & 4 & 5 & 6 \\
\hline Sebelum & - & - & - & +4 & - & - \\
\hline Tanpa Penambahan $\mathrm{NaCl}$ & - & - & - & +4 & - & - \\
\hline $3,5 \%$ & - & - & - & +4 & - & - \\
\hline $4,0 \%$ & - & - & - & +4 & - & - \\
\hline $4,5 \%$ & - & - & - & +4 & - & - \\
\hline
\end{tabular}

Berdasarkan tabel 1 menunjukkan bahwa kadar glukosa urine sebelum dan setelah diberikan perlakuan tidak mengalami perubahan atau penurunan kadar. 
Tabel 2. Hasil Pemeriksaan Leukosit Esterase Metode Carik Celup Sebelum dan Setelah Penambahan Larutan Garam NaCl

\begin{tabular}{c|cccccc}
\hline \multirow{2}{*}{$\% \mathrm{NaCl}$} & \multicolumn{7}{c}{ Replikasi } \\
\cline { 2 - 7 } Sebelum & 1 & 2 & 3 & 4 & 5 & 6 \\
\hline Tanpa penambahan $\mathrm{NaCl}$ & +3 & +2 & +2 & +1 & +2 & +2 \\
\hline $3,5 \%$ & +2 & +1 & +1 & - & +1 & +1 \\
\hline $4,0 \%$ & +2 & +1 & +1 & - & +1 & +1 \\
\hline $4,5 \%$ & +2 & +1 & +1 & - & +1 & +1 \\
\hline
\end{tabular}

Berdasarkan tabel 2 menunjukkan bahwa hasil pemeriksaan leukosit esterase pada setiap sampel mengalami peningkatan pada kelompok tanpapenambahan larutan garam $\mathrm{NaCl}$ (To).

Tabel 3. Hasil Pemeriksaan Nitrit Metode Carik Celup Sebelum dan Setelah Penambahan Larutan Garam NaCl

\begin{tabular}{c|cccccc}
\hline \multirow{2}{*}{$\% \mathrm{NaCl}$} & \multicolumn{7}{|c}{ Replikasi } \\
\cline { 2 - 7 } Sebelum & 1 & 2 & 3 & 4 & 5 & 6 \\
\hline Tanpa penambahan $\mathrm{NaCl}$ & - & - & + & - & - & + \\
\hline $3,5 \%$ & + & - & + & + & + & + \\
\hline $4,0 \%$ & + & - & + & + & + & + \\
\hline $4,5 \%$ & + & - & + & + & + & + \\
\hline
\end{tabular}

Berdasarkan tabel 3 menunjukkan bahwa hasil pemeriksaan nitrit pada kelompok sebelum relatif sama dengan hasil pemeriksaan nitrit pada kelompok perlakuan yang ditambahkan larutan garam $\mathrm{NaCl}$ (T1, T2, T3).

Tabel 4. Hasil Pemeriksaan Eritrosit Metode Carik Celup Sebelum dan Setelah Penambahan Larutan Garam NaCl

\begin{tabular}{c|cccccc}
\hline \multirow{2}{*}{$\% \mathrm{NaCl}$} & \multicolumn{7}{|c}{ Replikasi } \\
\cline { 2 - 7 } & 1 & 2 & 3 & 4 & 5 & 6 \\
\hline Sebelum & +1 & +1 & +1 & +1 & +2 & +2 \\
\hline Tanpa penambahan $\mathrm{NaCl}$ & - & +2 & - & - & +1 & +1 \\
\hline $3,5 \%$ & +1 & +1 & - & +1 & +2 & +2 \\
\hline $4,0 \%$ & +1 & +1 & - & +1 & +2 & +2 \\
\hline $4,5 \%$ & +1 & - & - & - & +1 & +1 \\
\hline
\end{tabular}

Berdasarkan tabel 4 menunjukkan bahwa hasil pemeriksaan eritrosit padakelompok tanpa penambahan $\mathrm{NaCl}$ cenderung mengalami penurunan. Sedangkan pada kelompok sebelum dan perlakuan relatif tetap

\section{Pembahasan}

Hasil pemeriksaan urine metode carik celup pada parameter glukosa, leukosit esterase, nitrit, dan eritrosit adalah sebagai berikut:

\section{a. Glukosa}

Hasil pemeriksaan glukosa urine menunjukkan bahwa tidak adanya perbedaan hasil pemeriksaan glukosa pada kelompok kontrol dengan kelompok perlakuan (To, T1, T2, T3). Hasil penelitian lain 
menunjukkan bahwa tidak ada perbedaan hasil urinalisis metode dipstik pada urine segar dan urine simpan 4 jam $^{8}$.

Dari 6 sampel urine penderita Diabetes Mellitus yang mengalami ISK, hanya satu sampel yang memiliki kadar glukosa urine positif (+4). Setelah diberikan perlakuan dan didiamkan selama 12 jam, tidak terjadi perubahan atau penurunan positivitas pada hasil glukosa urine. Hasil tersebut dikarenakan dalam urine tersebut bakteri yang ada dalam urine bukan termasuk bakteri fermentasi glukosa. Bakteri penyebab ISK yang tidak meragi glukosa adalah Pseudomonas aeruginosa.

\section{b. Leukosit Esterase}

Kadar leukosit esterase pada 6 sampel urine, menunjukkan hasil yang meningkat pada kelompok yang tidak diberikan larutan garam $\mathrm{NaCl}$ setelah didiamkan selama 12 jam. Hasil penelitian yang telah dilakukan oleh Kustiningsih dkk (2018), yang menyatakan bahwa jumlah leukosit pada urine mengalami penurunan jika disimpan selama 3 jam pada suhu kamar ${ }^{9}$.

Peningkatan kadar leukosit esterase pada metode carik celup karena prinsipnya yaitu mendeteksi enzim esterase yang dihasilkan oleh leukosit yang mengalami lisis. Enzim esterase ini akan muncul setelah adanya lisis dari membran leukosit yang menyebabkan granul azurofilik di dalam sitoplasma leukosit akan lisis sehingga pemeriksaan leukosit esterase akan menunjukkan hasil pemeriksaan yang meningkat dari sebelumnya $/$ positif palsu $^{10}$.

\section{c. Nitrit}

Hasil pemeriksaan nitrit pada 6 sampel urine penderita DM yang mengalami ISK menunjukkan hasil yang bervariasi. Dimana pada 3 sampel terjadi perubahan nitrit yang semulanya positif $(+)$ pada kelompok kontrol, menjadi negatif (-) pada kelompok perlakuan (To). Hasil negatif (-) pada To dapat disebabkan karena adanya proses denitrifikasi oleh bakteri denitrifikasi. Bakteri denitrifikasi merupakan bakteri yang memanfaatkan senyawa nitrat sebagai penerima elektron terakhir, dimana nitrat akan direduksi menjadi nitrit kemudian membentuk gas nitrogen. Reduksi nitrit menjadi gas nitrogen bebas dibantu oleh enzim Nitrous Oksida Reduktase. Bakteri yang memiliki enzim tersebut adalah bakteri Pseudomonas Aeruginosa.

Bakteri ini merupakan salah satu penyebab ISK pada manusia.Bakteri ini dapat mereduksi nitrat dengan produk akhir berupa gas nitrogen (N2) karena didukung dengan kelengkapan enzim Nitrat Reduktase, enzim Nitrit Reduktase, dan enzim Nitrous Oxide Reduktase ${ }^{11}$.

Pada sampel 2, 3, dan 6 tidak terjadi perubahan nitrit pada kelompok sebelum perlakuan dengan kelompok perlakuan. Pada sampel 2, hasil pemeriksaan nitrit sebelum perlakuan (kontrol) adalah negatif (-). Hasil tersebut di karenakan walaupun terdapat bakteri denitrifikasi dalam urine tersebut, hasil pemeriksaan nitrit akan tetap negatif (-) karena tidak ada nitrat dalam urine yang akan direduksi menjadi nitrit oleh bakteri. Sedangkan pada sampel 3 dan 6, hasil pemeriksaan nitrit sebelum perlakuan (kontrol) dan setelah perlakuan (To, T1, T2, T3) adalah positif (+). Hasil nitrit pada To tidak mengalami perubahan menjadi negatif (-) seperti pada sampel lainnya. Kandungan nitrit dapat hilang dari urine jika di reduksi oleh enzim Nitrous Oxida Reduktase menjadi gas nitrogen (N2). Jika aktivitas enzim tersebut berjalan dengan lambat, maka nitrit tidak akan tereduksi sehingga akan tetap berada dalam urine walaupun urine didiamkan selama 12 jam.

\section{d. Eritrosit}

Hasil pemeriksaan eritrosit menunjukkan hasil yang cenderung menurun pada urine yang didiamkan selama 12 jam tanpa penambahan larutan 
garam $\mathrm{NaCl}$. Prinsip pemeriksaan eritrosit pada carik celup adalah mengukur kadar hemoglobin yang dihasilkan karena eritrosit mengalami lisis. Pada penambahan larutan garam konsentrasi 3,5\% dan $4,0 \%$, hasil pemeriksaan eritrosit cenderung konstan karena tidak mempengaruhi membran eritrosit. Membran plasma eritrosit bersifat permeabel terhadap molekul air (H2O). Sel darah yang dimasukkan dalam larutan hipertonis akan mengalami krenasi (pengerutan) sel karena lebih banyak air yang keluar sel daripada yang masuk. Demikian sebaliknya, apabila eritrosit berada dalam lingkungan yang hipotonis, maka osmosis akan terjadi dari luar ke dalam sel yang akan menyebabkan sel akan menggembung. Apabila

\section{Kesimpulan}

Berdasarkan hasil penelitian yang telah dilakukan, dapat disimpulkan bahwa larutan garam $\mathrm{NaCl}$ konsentrasi $3,5 \%$ dan $4,0 \%$ dapat dimanfaatkan sebagai pengawet alternatif untuk

\section{Daftar Pustaka}

1. Lembar, S., \& dkk. (2012). Urinalisis \& Pemeriksaan cairan Tubuh sederhana. WIMI. Jakarta

2. Utsch, B., \& Klaus, G. (2014). Urinalysis in children and adolescents. Deutsches Arzblatt International Medicine.

3. Hartawan, M., Taza, H., Sukriyadi. (2012). Hubungan antara pemasangan kateter tetap dengan kejadian infeksi saluran kemih pada pasien rawat inap di RSUD laparatai kabupaten barru. STIKES nani hasanudin makasar. 1(4): 1-8

4. Gandasoebrata, R. (2010). Penuntun Laboratorium Klinik (Edisi 16). Dian Rakyat: Jakarta

5. Karsinah, L.H.,Suharto, \& Mardiastuti, membran plasma tidak dapat menahan tekanan tinggi intrasel tersebut, maka sel akan pecah dan hemoglobin akan dilepaskan ${ }^{12}$.

Hasil yang menurun pada sampel yang didiamkan selama 12 jam tanpa penambahan larutan garam $\mathrm{NaCl}$ disebabkan karena eritrosit mengalami lisis jika didiamkan selama beberapa jam. Urine yang jika tidak segera diperiksa dan disimpan terlalu lama, maka $\mathrm{pH}$ akan berubah menjadi basa. Urine dengan $\mathrm{pH}$ basa dapat menyebabkan hasil negative atau penurunan jumlah eritrosit. Eritrosit juga dapat mengalami lisis jika berat jenis urine $<1,010$ karena akan menyebabkan sel eritrosit mengembang kemudian lisis ${ }^{8}$.

pemeriksaan leukosit esterase, nitrit, dan eritrosit pada urine. Sedangkan larutan garam $\mathrm{NaCl}$ tidak berpengaruh terhadap kadar glukosa urine.

H.(1993). Mikrobiologi Kedokteran. Universitas Indonesia

6. Fajriputri, H. (2014). Uji Koefesien Fenol Produk Antiseptik Dan Desinfektan Yang Mengandung Senyawa Aktif Benzalkonium Klorida. Universitas Islam Negeri Syarif Hidayatullah.

7. Rahayu, W. (2013). Penentuan Konsentrasi Hambat Minimum (Khm) Ekstrak Buah Melur (Brucea Javanica) Terhadap Bakteri Escherichia Coli Dan Staphylococcus Aureus Secara In Vitro. Universitas Negeri Padang.

8. Tarigan, O.N. (2018). Perbedaan Hasil Urinalisis Metode Dipstik Pada Urine Segar, Urine Simpan 4 Jam Suhu Ruangan, dan Urine Simpan 4 Jam Suhu $2-8^{\circ} \mathrm{C}$.

\footnotetext{
Korespodensi: baiq nasha islaeli, nashaislaeli@yahoo.co.id, 081805556755, Jurnal Analis Medika Bio Sains, Volume X No. X, FebruariX |
} 
Universitas Lampung

9. Kustiningsih, Y.,Cahyono, J.A., Rahmiati, N. (2016). Pengaruh Lama Penyimpanan Urine Pada Suhu Kamar Terhadap Jumlah Leukosit Studi Pada Penderita Diabetes Mellitus

10. Brunzel, A.N. (2004). Fundamental on Urine \& Blood Analysis. Ed.2. USA: Saunders

11. Rusmana,I. (2006). Gaseous End Products of Nitrat and Nitrite Reduction by Denitrifying Pseudomonad Isolated from Estuarine Sediment. Jurnal Mikrobiologi Indonesia, p.63-66

12. Paleari, dkk. (2008). Controversies on the Osmotic Fragility Test. Milan University of Milano 